\title{
THE PROPOSED FEDERAL CHILD CARE CORPORATION
}

Increasing concern with poverty in America has stimulated deeper examination of the federal government's efforts to promote nationwide full employment, since poverty is usually associated with long-term unemployment. Attacks on unemployment have, not surprisingly, focused on making job opportunities available, to the neglect of a quite different aspect of unemployment: the general unavailability of daytime child care enabling mothers of small children to seek jobs. ${ }^{1}$ Women heading families need special attention because they are often their families' only breadwinners ${ }^{2}$ and poverty will afflict their families if they cannot work, as evidenced by the fact that many of the families supported by public assistance are fatherless families with an unemployed mother. ${ }^{3}$ Whether the present market could employ all mothers who cannot work now because they have children to care for and whether such mothers want to work is not known. ${ }^{4}$ But plainly this largest and fastest growing portion of the welfare population-families headed by women ${ }^{5}$-cannot become self-sustaining and leave the welfare rolls unless child day care is available. ${ }^{b}$ Day care, then, may be one key to curbing recently soaring welfare costs. Yet day care has not been widely available, ${ }^{7}$ despite private and public efforts to offer it. A recent

1 A 1965 study reveals the enormity of the task involved: a day care need was felt for 2.7 million children, yet only 310,000 were cared for in both public and private licensed day care centers. ADvisory CouncIl on PUBLIC WelFare, U.S. Dep't of Healte, Enuc., \& Welfare, Having the Power, We Have the Duty 58 (1966). In 1970, over 4 million working mothers had children under 6 years old. Only 640,000 licensed day care spaces were available. N.Y. Times, Nov. 30,1970 at 1 , col. 6 (city ed.). In New York City alone day care could benefit 250,000 to 400,000 children and their parents. N.Y. Times, Mar. 22, 1971, at 29, col. 1 (city ed.).

2 The median annual income of families headed by women was only $\$ 3532$ in 1965. Carter, The Employment Potential of AFDC Mothers: Some Questions and Some Answers, 6 Welfare IN Rev., July-Aug. 1968, at 1, 3.

3 About 95\% of adult AFDC recipients in 1968 were women. U.S. DEP'T oF Labor, THE Work INCENTIVE PROgRaM: FIRST ANNUAL REPORT OF THE DEp'T OF Labor to the Congress an Tratning and Employment Under Title IV of the Soctal SECURITY ACT (1968).

4 It has been asserted, however, that the paucity of child care facilities has been the greatest obstacle to the employment of mothers. Warren \& Berkowitz. The Employability of AFDC Mothers and Fathers, 7 WeLfare IN REV., July-Aug. 1969, at 1,5 .

5 See note 3 supra.

${ }^{6}$ This Comment will not discuss two other possible governmental solutions: (1) simply discontinuing welfare payments, or (2) attempting to reduce the number of broken homes and children born into fatherless families. Another important problem beyond the scope of this Comment is whether under present economic and social conditions day care, without more, would simply enable poor women to take menial, low-paying, and degrading jobs, potentially hindering rather than helping their escape from the poverty cycle. Cf. Mrssissippi State Advisory Comm., Welfare in Mississippi: A Report to the U.S. CoMm'N ON CIVIL RIGHTS 32 (1969), excerpted in $2 \mathrm{E}$. Sparer \& $H$. Freedman, Materials on Public Assistance and Income Maintenance Programs 5-119, 5-122 to -123, Summer 1970 (unpublished materials for use at University of Pennsylvania Law School).

7 Advisory Council on Public Welfare, sulpra note 1 , at 55-58. 
innovative proposal for making day care available to all families desiring it is a Federal Child Care Corporation, the subject of a bill (S. 2003) presently before Congress. ${ }^{8}$ After discussing the strengths and shortcomings of past approaches to providing day care, this Comment will examine whether the Child Care Corporation legislation improves upon the experiences of past programs. It will be seen that day care programs have typically been plagued with insufficient funding, poor program planning, and decentralized administration, and that the proposed corporation avoids many of the pitfalls of earlier attempts but could still be improved in the areas of fees for services to the poor and community input.

\section{Private, Local, and State Day Care}

Many existing day care facilities are privately operated. ${ }^{9}$ Private facilities, however, have been inadequate to meet the entire need for day care, for two reasons. First, day care is too costly to be provided to the poor without public or charitable subsidization, ${ }^{10}$ and second, governmental regulations and licensing requirements can be so numerous or inconsistent that the lawful operation of facilities becomes difficult or impossible.

The high cost of day care is a serious problem ${ }^{11}$ and makes necessary government aid to day care centers; yet even when subsidized by charitable organizations, child care is often too expensive for the poor. ${ }^{12}$ Being primarily local enterprises, day care centers do not find lowincome areas profitable locations. Thus privately supported centers generally locate in middle- and upper-income areas, ${ }^{13}$ and in areas of high unemployment, where few can afford day care, none is available.

8 S. 2003, 92d Cong., 1st Sess. tit. III (1971).

- See Health \& Welfare Councit of the Baltmore Area, Inc., Day Care NeEds In Maryland 24 (1964) [hereinafter cited as Maryland DaY Care]; U.S. Dep'T of Healte, Educ. \& Welfare \& N.Y. Dep't of Soctal Services, The Administration of AID to Families with Dependent CHIIDRen in New York CITY 139 (1969) [hereinafter cited as N.Y.C. AFDC]; N.Y. Times, Nov. 30, 1970, at 1 , col. 6 (city ed.).

10 See Maryland Day Care, supra note 9, at 25.

11 S. Law \& P. Spindler, Child Care Arrangements of Working Mothers In the United States 24 (1968); see Maryland Day Care, supra note 9, at 24-25. Operational costs per child range around $\$ 10$ to $\$ 40$ a week, compared with a schooling cost of about \$22. See MARYLAND DAY CARE, supra note 9, at 53; N.Y.C. AFDC, supra note 9, at 139; Auerbach Corp., Resident Observation: The Work Incentive Program, Florence Office, Ios Angeles County D-7, Mar. 15, 1970 (report submitted to Office of Evaluation, Manpower Admin., U.S. Dep't of Labor); N.Y. Times, Nov. 30,1970 , at 1 , col. 8 (city ed.).

12 See Massachusetis Comar. on Chindren \& Youth, Day Care for Chimdren IN MASSACHusetrs 12-13 (1966) [hereinafter cited as MASSACHusetTs Day Care].

13 See Welfare Counch of Metrofolitan Chicago, Day Care for Chindren In Chicago: Needs AND Resources, BY Comarunity Areas 4 (1967); Note, Observations on the Establishment of a Child-Protective-Services System in Califormia, 21 STAN. L. REv. 1129 n.5 (1969). New York City has recognized the problem and planned 123 new day care centers in slum areas. N.Y.C. AFDC, supra note 9 , at 139 . 
Public centers charging fees to cover their full costs are no better solution to the child care needs of the poor since such operations can be supported only by those able to afford them. With poor families unable to bear the high cost, day care services can realistically be offered them only through tax-supported government subsidies. Yet so far no governmental unit has committed adequate funds to meet the entire day care needs of its citizens.

Licensing and regulation have posed a further difficulty for private agencies, which often face restrictive and inconsistent requirements imposed at the local, state, and federal levels. ${ }^{14}$ A center may have to comply with building codes, zoning classifications, health and safety standards, insurance requirements, a variety of program standards, staff certification and training standards, staff-child ratios, space requirements, and advertising restrictions, some of which may be imposed by more than one level of government. As suggested by one study, compliance with all regulations may be virtually impossible. ${ }^{15}$ Licensing and regulation are necessary to prevent substandard care, ${ }^{16}$ but coordination would be desirable, and regulation should be centralized in one department of one level of government.

\section{Federal-State Dax Care}

An alternative approach to day care has involved both the federal and state governments in cooperative funding and administration of various welfare and antipoverty programs. The federal government, however, has never established a distinct day care program, but, rather, has subsidized day care as part of broad campaigns against problems of poverty, unemployment, and education. ${ }^{17}$ Two programs, Aid

I4 See, e.g., Marytand Day Care, supra note 9, at 15-17; Inlinors Dep'T of Chindren \& Family Services, Standards for Licensed Day Care Centers and Grout Day Care Faciltties (1967); cf. Chitld Welfare league of America, Standards for Day Care Services (1960).

For examples of state licensing laws and procedures, see N.Y. Soc. WeLfare LAw $\$ 390$ (McKinney 1966) ; PA. Stat. ANN. tit. 62, \$\$ 1001-59 (1968). In Metropolitan Ass'n of Private Day Schools, Inc. v. Baumgartner, 41 Misc. 2d 560, 245 N.Y.S.2d 733 (Sup. Ct. 1963), the court upheld those sections of the New York City Health Code dealing with regulation of day care service as applied to private institutions. But a child care licensing law which leaves unqualified discretion in an administrative official may be unconstitutional. See State v. Gilroy, 37 Wash. 2d 41, 221 P.2d 549 (1950).

The recently promulgated Federal Interagency Day Care Requirements set standards applicable to all day care projects receiving federal funds. 45 C.F.R. $\$ 71$ (1971).

15 Auerbach Corp., supra note 11, at D-2, D-3. See also Paulsen, The Licensing of Child-Care Facilities-A Look at the Law, 21 ALA. L. REv. 1 (1968).

16 See F. Ruderman, Child Care and Working Mothers 90 (1968).

17 See Elementary and Secondary Education Act of 1965, 20 U.S.C. $\$ \S 241 \mathrm{a}-\mathrm{m}$ (Supp. V, 1970) (aid to preschool programs in low-income areas); Housing and Urban Development Act, 42 U.S.C. \$3103 (Supp. V, 1970) (grants for portion of development costs of certain day care facilities); Model Cities Act, 42 U.S.C. $\$ \$ 3301-74$ (Supp. V, 1970); H.R. 16311, 91st Cong., 2d Sess. (1970) (proposed Family Assistance Plan); H.R. 13472, 91st Cong., 2d Sess. $\$ 101$ (1970) (proposed Manpower Training Act). Congress has also recognized the social utility of minimizing individual responsibility for child care expenses by permitting a tax deduction 
to Families with Dependent Children (AFDC) ${ }^{18}$ and the Work Incentive Program, ${ }^{19}$ offer federal aid to a range of state antipoverty activities, including child care, and, thus, merit evaluation here.

The AFDC program is part of the Social Security Act of $1935 .^{20}$ In 1962 the child welfare provisions ${ }^{21}$ of AFDC ${ }^{22}$ were broadened to require improvement and expansion of federally assisted state child welfare programs, and federal money was declared available for "childwelfare services," which were defined broadly to include day care of children of working AFDC mothers. ${ }^{23}$ The 1962 amendments took commendable steps to make educational and health services part of day care, to improve expert participation in program planning, and to assure that limited day care services were offered first to poor families. To these ends the amendments required the states to maximize their use of the resources of state education and health agencies in providing day care, to set up day care advisory committees comprising representatives of state agencies and private groups concerned with day care, to limit federally supported day care services to needy cases where in the best interest of child and mother, and to give priority to low-income groups. ${ }^{24}$ Child care was to be provided for children of participants in Community Work and Training, a large-scale job retraining program. ${ }^{25}$

The obviously increased emphasis on and improvements in day care did little, however, to enable welfare mothers to work, primarily due to three congressional budgeting decisions. First, although the 1962 amendments authorized the appropriation of $\$ 10$ million for day care in fiscal $1965,{ }^{26}$ Congress later appropriated only $\$ 4$ million. ${ }^{27}$ At the same time, Congress eliminated earmarking for day care ${ }^{28}$ - that is, while the AFDC appropriation included an amount for day care, the funds were available to the states in a lump sum to spend as they saw fit. The decision not to earmark reflected Congress' belief that state awareness of the need for day care had advanced sufficiently to ensure that they would establish day care programs without the compulsion of earmarking. ${ }^{29}$ This belief might have been justified had not Congress

for such care if it enables the taxpayer to be gainfully employed. INT. REv. CodE of $1954, \S 214$.

1842 U.S.C. $\$ \$ 601-44$ (Supp. V, 1970), antending 42 U.S.C. $\$ \$ 601-09$ (1964).

19 Id. $\$ \$ 602(a)(19), 630-44$ (Supp. V, 1970).

20 Act of Aug. 14, 1935, ch. 531, 49 Stat. 620, as amended, 42 U.S.C. \$\$ 301-1394 (1964), as anended, 42 U.S.C. $\$ \$ 301-1394$ (Supp. V, 1970).

21 Public Welfare Amendments of 1962, Pub. L. No. 87-543, 76 Stat. 172 (codified in scattered sections of 42 U.S.C.).

2242 U.S.C. $\$ \$ 721-28$ (1964), as amended, 42 U.S.C. $\$ \S 620-26$ (Supp. V, 1970). 23 Id. $\$ \$ 723,728$ (1964), as amended, 42 U.S.C. $\$ \S 610,625$ (Supp. V, 1970).

24 Id. $\$ 723$ (a) (1964), as anended, 42 U.S.C. \$622(a) (Supp. V, 1970).

25 Act of July 25, 1962, Pub. L. No. 87-543, 76 Stat. 187 (repealed 1968).

26 Act of July 25, 1962, Pub. L. No. 87-543, $\$ 102($ c) (1), (2), 76 Stat. 183 (repealed 1968).

27 Act of Sept. 19, 1964, Pub. L. No. 88-605, 78 Stat. 975.

28 Day Care in Danger, 44 CHIn Welfare 4 (1965) (editor's page).

29 See 111 CoNG. Rec. 11038 (1965) (remarks of Senator Ribicoff). 
taken the third step of cutting back the rate of federal financial participation in state day care programs to fifty percent of their cost beginning in $1966,,^{30}$ probably with the effect of encouraging the states to operate instead other antipoverty programs offering a higher percentage of federal funding. ${ }^{31}$ States now had to provide only a very low percentage of the cost of other federally assisted antipoverty programs, but had to pay half the cost of day care. The elimination of earmarking freed the states to ignore day care in favor of programs under which states received more benefit for the same cost.

Another federal welfare program, the Work Incentive Program (WIN) ${ }^{32}$ was designed to break the cycle of poverty by encouraging the poor to find jobs. Added to the Social Security Act in 1968,33 WIN requires the states to develop for each adult receiving AFDC payments an individualized plan designed to lead to his employment. ${ }^{34}$ The work incentive itself is a small monthly payment to those who take jobs ${ }^{35}$ plus the threat of discontinuance from the welfare rolls for failure, without good cause, to accept "appropriate" jobs. ${ }^{36}$ Mothers who cannot arrange for care of their children, though, are exempted from the program. ${ }^{37}$ With women constituting the bulk of the welfare rolls, ${ }^{38}$ WIN can have little impact unless day care is widely available. ${ }^{39}$ In fact, WIN has so far been a failure. ${ }^{40}$ Day care did not materialize, ${ }^{41}$ despite the availability of federal funds to bear seventy-five percent of the operating costs of day care facilities for children of WIN workers. ${ }^{42}$

30 Act of Sept. 19, 1964, Pub. I. No. 88-605, 78 Stat. 976.

31 See Day Care in Danger, supra note 28, at 4; cf. Advisory CouncIl on Public Welfare, supra note 1 , at $36-37$.

3242 U.S.C. $\$ \S 602$ (a) (19), 630-44 (Supp. V, 1970).

33 Act of Jan. 2, 1968, Pub. L. No. 90-248, \$204, 81 Stat. 884.

34 See 42 U.S.C. $\S \S 630-44$ (Supp. V, 1970).

$35 \mathrm{Id}$. $\$ 634$.

36 See id. $\S 602(\mathrm{a})(19)(\mathrm{F})$.

3745 C.F.R. $\$ 220.35$ (a) (2) (v) (1971).

38 Note 3 supra.

39 A flat exemption for mothers with preschool children was deleted at the conference stage. CoNF. REP. No. 1030, 90th Cong., 1st Sess. (1967), reprinted in 1967 U.S. CoDE CoNG. \& AD. NEWs 3179, 3204. See F. Arner, The Work Incentive (WIN) Program: Establishment and Early Implementation 41, June 5, 1969 (U.S. Library of Congress, Legislative Reference Service ed. 378). See also S. REP. No. 744, 90th Cong., 1st Sess. (1967), reprinted in 1967 U.S. Cone Cong. \& AD. News 2834, 3123-24; 113 CoNG. Rec. 36,368 (1967).

40 See Comment, The Failure of the Work Incentive (WIN) Program, 119 U. PA. L. REv. 485 (1971).

41 See Auerbach Corp., Report on WIN Program Supplement to Oral Presentation 4, Apr. 24, 1969 [hereinafter cited as Auerbach Report].

4245 C.F.R. $\$ \$ 220.61$ (e) (11), (f) (1971) (federal financial participation at the rate of $85 \%$ for the fiscal year ending June 30,1969 , and at $75 \%$ for subsequent fiscal years); Day Care Program, 1 CCH URBAN AFFAIRS REP. $\pi 7132$ (1970) (citing Women's Bureau, Wage and Labor Standards Admin., U.S. Dep't of Labor, Feb. 1969); Work Incentive Program, 1 CCH URBAN AFFaIRS REP. 18341 , at 2643 (1969). Although day care services must be furnished to every person referred to and enrolled in the WIN program, 45 C.F.R. \&220.18(a) (1971), this regulation is significantly diluted by the concomitant exemption from mandatory referral of persons 
Several reasons have been suggested to explain the states' failure to set up many day care centers in conjunction with WIN. Particularly important was said to be the lack of federal assistance for development and construction costs of day care facilities, since the states could not start a program without bearing the full start-up costs. Another reason given was the difficulty of planning a facility meeting all the federal, state, and local requirements. Finally, existing resources were largely ignored by WIN administrators, who did little to coordinate the day care needs of their program with the services offered by centers already in operation. ${ }^{43}$

Congress, then, has apparently been aware of the importance of day care to the improvement of social welfare, ${ }^{44}$ but federal-state programs have largely proved inadequate. Reliance upon the states to develop program details and to bear the cost of development and construction, ${ }^{45}$ without provision of sufficient inducements, has left day care needs unmet. $^{46}$

\section{Wholly Federal Programs}

The experiences of local, state, and joint federal-state programs suggest that a wholly federal approach to providing day care might better offer the larger-scale centralized planning and complete funding necessary to success. However, while showing adequate planning, national programs have suffered from insufficient scope and funding.

The day care provisions of the Economic Opportunity Amendments of $1967^{47}$ were designed to provide the child care necessary to enable parents or caretaker relatives of needy children to undertake or continue employment. ${ }^{48}$ The government was to bear nearly all the costs of care, with payments authorized for up to ninety percent of the planning and operating costs of projects run by public agencies and private organizations, including renovation and alteration of buildings. ${ }^{49}$

"whose presence in the home is required because adequate child-care services cannot be furnished," $i d$. $\$ 220.35$ (a) (2) (v) (1971). Thus a state can avoid referring those constituting the bulk of the welfare rolls merely by deciding that child care cannot be furnished. Apparently the practice has been to tell mothers that they can enroll in WIN only if they can get child care. Auerbach Report, supra note 41 , at 4 . Despite the required provision of services, many mothers have had to drop out of WIN because of the lack of appropriate continuous care. $I d$., pt. 2, at 2 .

43 See Auerbach Report, supra note 41, at 4.

44 Cf. 45 C.F.R. $\$ 220.18$ (a) (1971) (child care must be available to all WIN participants).

45 It has been said that the biggest problem and handicap in efforts to establish new day care centers is the absence of planning resources. N.Y. Times, Mar. 23, 1971, at 1, col. 4 (city ed.).

46 See also Advisory Councin on Public Welfare, supra note 1, at 36; CoMMITTEe FOR Economic DeveropMent, Improving THE PUblic Welfare System 44-46 (1970).

47 Act of Dec. 23, 1967, Pub. L. No. 90-222, $\$ 107$ (a), 81 Stat. 672, 713 (codified in scattered sections of ch. 34,42 U.S.C.).

48 See 42 U.S.C. $\$ 2931$ (Supp. V, 1970).

49 See $i d, \$ 2932(a)$. Financial assistance under the Economic Opportunity Amendments was to be available independent of or in conjunction with day care projects funded under the Social Security Act. Id. 
Additionally, for the first time extensive federal attention was to be paid to program planning, with the goal of "a common set of program standards and regulations, and mechanisms for coordination at the State and local levels." 50 Program evaluation by independent sources was specifically required. ${ }^{.1}$

This day care program showed promise because comprehensive funding was authorized and the federal government was to participate in program planning. Unfortunately the effectiveness of this departure from previous programs, which had ignored capital costs and left program development to state agencies, cannot be evaluated because the program was never allocated any funds. ${ }^{52}$

Another federal program, Project Head Start, ${ }^{53}$ has proved a distinct success in providing day care, but on such a limited scale that it ought to be considered a pilot project. Head Start was designed to combat the roots of poverty by providing preschool education and nutritional, health, and social services in poor areas. ${ }^{54}$ Although it allocated funds to local agencies, ${ }^{55}$ the program was planned completely on a national level, ${ }^{\tilde{\sigma} 6}$ and local groups merely implemented the plan. Originally a summer program, Head Start has been expanded in some localities into a year-long project serving poor children up to seven hours per day-effectively providing day care as well as preschool education. ${ }^{57}$ The program is effective because it combines health care and education with custodial care, provides free services to the poor, and uses local resources and talent organized by a national administration. ${ }^{58}$ But the program also has certain deficiencies-it makes only minimal use of existing private child care resources ${ }^{59}$ and has been implemented too narrowly to meet the child care needs of more than a relative few. ${ }^{60}$

Thus, past approaches to providing day care have failed in one way or another. State and private programs have lacked adequate financing and coordinated administration and regulation. The child care pro-

50 Id. $\$ 2932$ (d).

51 Id. $\$ 2932(\mathrm{e})$.

52 See S. REp. No. 453, 91st Cong., 1st Sess. 34 (1969). Congress did, however, extend the authorization two years to June 30, 1972. Act of Dec. 30, 1969, Pub. L. No. 91-177, \$101 (c), 83 Stat. 827 (codified at 42 U.S.C. \$2933 (Supp. V, 1970)).

5342 U.S.C. $\$ 2809$ (a) (1) (Supp. V, 1970).

54 For a general discussion of the Head Start Program, see S. Levitan, The Great Society's Poor LaW 133-63 (1969).

55 See 42 U.S.C. $\$ 2812$ (a) (Supp. V, 1970).

66 See id. $\$ 2809$ (a) ; S. Levitan, supra note 54, at 137, 138.

57 See S. Levitan, supra note 54, at 138; Stewart, Day Care: An Under-Used Resource in Child Welfare, 47 ChIID Wedfare 207, 208 (1968) ; N.Y. Times, Nov. 30,1970 , at 1 , col. 8 (city ed.).

58 See 42 U.S.C. $\$ 2809$ (a) (1) (Supp. V, 1970); S. LEvITAN, supra note 54, at 143-44; N.Y. Times, Jan. 11, 1971, at 74, cols. 1-2 (city ed.).

59 Cf. S. LevtTaN, supra note 54, at 150 (text and table 4-9).

60 S. LeVitan, supra note 54, at 140; 113 CoNG. REc. 16,032 (1967) (remarks of Senator Javits). 
visions of jointly administered state-federal welfare programs have likewise suffered from insufficient funding, diffusion of program planning responsibility, and treatment of day care as a subsidiary aspect of scattered programs rather than an independent goal of a unified program. Finally, the one wholly federal program receiving funding, though successful, was implemented on only a small scale. A new plan for comprehensive day care should avoid these deficiencies: it should recognize day care as a distinct societal need and deal with it in a unified program; it should offer adequate funding for nationwide implementation; and it should provide a unified planning and administrative structure. A Federal Child Care Corporation as proposed in S. 2003 could, with certain modifications, deal adequately with the problem.

\section{The Federal Child Care Corporation}

The proposed legislation would add to the Social Security Act a new title establishing a Federal Child Care Corporation with "the duty and function . . . to meet, to the maximum extent economically feasible, the needs of the Nation for child care services." 61 Endowed with broad powers to hold property and make contracts, the corporation would specifically have the powers necessary to provide day care, contract with others for day care services, design and construct facilities, and cooperate with other organizations providing day care. ${ }^{62}$ The corporation would be financed by payment for services provided, ${ }^{63}$ Treasury loans up to $\$ 500$ million to be used for any of the corporation's purposes, ${ }^{64}$ and bonds up to $\$ 250$ million for planning, construction, and equipment. ${ }^{6 \check{5}}$

The proposal has significant advantages over prior approaches. Its mandate to satisfy the nation's total need for day care ${ }^{66}$ contrasts favorably with prior programs, which neither recognized child care as a distinct area of social need nor attempted to attack the entire problem. The administrative structure is well suited to avoid the inefficiency of duplicated local effort, varying standards of care, and local indifference. Responsibility for the program is centrally located. ${ }^{67}$ The bill sets national standards of care, ${ }^{88}$ and the corporation's operations would be freed from local regulation. ${ }^{69}$ Another asset of the bill is that it calls for location of child care centers near the homes of the children to be

61 S. 2003, 92 d Cong., 1st Sess. $\$ 302$ (1971) (proposed Social Security Act $\S 2003(\mathrm{a}))$.

62 Id. (proposed Social Security Act $\$ 2007(\mathrm{a})$ ).

63 Id. (proposed Social Security Act $\$ 2003$ (b) (2)).

64 Id. (proposed Social Security Act $\$ 2010$ ).

65 Id. (proposed Social Security Act $\$ 2011$ ).

60 See id. (proposed Social Security Act $\$ 2001$ (b)).

67 The powers and duties of the corporation are to be vested in a Board of Directors. Id. (proposed Social Security Act $\$ 2002$ (b) (1)).

68 Id. (proposed Social Security Act \$2004).

69 Id. (proposed Social Security Act $\$ 2006($ a)). 
served and near other recreational and educational facilities. ${ }^{70}$ The central administration would be handled by experts: three full-time directors appointed by the President for staggered three-year terms, ${ }^{71}$ advised by a council of three cabinet members and twelve individuals representing social workers, educators, "consumers of child care," and public assistance recipients. ${ }^{72}$

While such forward strides are commendable, the proposal is defective where it fails to apply the experiences of the past. The opportunity for community input seems inadequate because the proposed national administrative structure could be insensitive to local conditions and perhaps even to the needs of the corporation's clients generally. ${ }^{\mathbf{7 3}}$ Project Head Start allowed local input which did not significantly impair central planning. The corporation would have to make full use of its power to cooperate with locally oriented agencies ${ }^{74}$ to remedy its community input deficiency. Local advisory councils would prove helpful and would certainly fall within the power "to do any and all things necessary, convenient, or desirable to carry out the purpose of this title . . ."75 But to ensure community input Congress should amend the bill to require such councils.

Nor is the fee structure or the planned reliance on fees to finance part of the program's cost ${ }^{76}$ satisfactory. Past day care provisions tended to concentrate on eliminating poverty and unemployment to the neglect of the need for day care in general, but by requiring the corporation to charge a uniform fee for its services, ${ }^{77}$ the new proposal makes the opposite mistake. The uniform fee seems flatly inconsistent with the awareness represented by the declaration that "low income families and dependent families are severely handicapped in their efforts to attain or maintain economic independence by the unavailability of adequate child care services . . . " 78 The fee arrangement may reflect the belief that the dignity and independence of the poor will be enhanced if they pay their full share, but the goal could prove overly optimistic. Day care costs would be in effect a reduction of working mothers' earnings and, combined with the reduction of the monthly welfare payment

70 Id. (proposed Social Security Act $\$ 2005(b))$.

71 Id. (proposed Social Security Act $\$ 2002(\mathrm{~b})$ ).

72 Id. (proposed Social Security Act $\$ 2018$ ).

73 Cf. J. IIndsay, The CITY (1969) ; N.Y. Times, Jan. 11, 1971, at 74, col. 1 (city ed.). The bill improves slightly upon its predecessor, $S .4101,91$ st Cong., 2d Sess. (1970). Proposed \$\$2006(b) and 2008 allow for a limited degree of community input, and proposed $\$ 2002(\mathrm{~b})(2)$ requires that the three directors must be "interested in the welfare of children and ... support the aims and objectives" of the proposed Act.

74 See S. 2003, 92d Cong., 1st Sess. \$302 (1971) (proposed Social Security Act $\S \S 2007$ (a) (5), (10), (11), (16)).

75 Id. (proposed Social Security Act $\$ 2007$ (a) (17)).

$76 I d$. (proposed Social Security Act $\$ 2010(\mathrm{~b})(2)$ ).

77 Id. (proposed Social Security Act $\$ 2003$ (b) (2)).

78 Id. (proposed Social Security Act $\$ 2001$ (a) (2)). 
by two-thirds of all income earned after the first $\$ 30,{ }^{79}$ may significantly impair welfare mothers' incentive to work. By charging poor families for day care services, the program, instead of fostering a sense of selfworth, may merely cause some to ignore the available services and to stay home to care for their children or leave their children unattended while they work.

Nor does the provision for public payment of an individual's child care fees ${ }^{80}$ alleviate the problem sufficiently. Relying on state welfare agencies to make these payments, without requiring that they do so, is certain to produce problems in administration. This is merely a complicated way of providing free services, and poor families ineligible for welfare would have to pay the full cost of day care themselves.

A more sensible arrangement would adjust fees according to the family's ability to pay, ${ }^{81}$ with the Treasury subsidizing the operation directly. This might result in increased use of the facilities and an accompanying thrust toward the eventual goal of a self-supporting program.

\section{Conclusion}

The enormous need for day care services for children has not been met. At low income levels the availability of child care freeing parents for employment might be the turning point for many families trying to escape the cycle of poverty. Day care can be essential to the success of a number of federal poverty programs, yet its importance has hitherto gone unrecognized to the extent that day care has never been seen as a goal apart from other welfare programs. Child care lies at the confluence of manpower and welfare policies, but past programs have suffered from underfunding, administrative unmanageability, and narrowness of scope. The Federal Child Care Corporation proposal seems to recognize that child care is necessary to fill a distressing vacuum in federal antipoverty legislation, and, with some modifications, it will be a credit to the Congress that enacts it.

79 42 U.S.C. $\$ 602$ (a) (8) (Supp. V, 1970).

80 S. 2003, 92d Cong., 1st Sess. $\$ 302$ (1971) (proposed Social Security Act $\$ \$ 2003(\mathrm{~b})(2),(3))$.

81 Making services available to all and charging according to ability to pay rather than providing limited services available only to the poor has the advantage of promoting economic heterogeneity within the centers. This would be an asset since poor children probably develop faster in groups where they are not economically segregated. N.Y. Times, Mar. 23, 1971, at 1, col. 4 (city ed.). 